\title{
Publication Parameters for Medical Faculty Promotions: A Survey on the Medical Council of India Amendment 2019 with Review of Literature
}

\author{
Anurima Patra ${ }^{1} \quad$ Sridhar Gibikote ${ }^{1} \quad$ Pushpinder S. Khera ${ }^{2} \quad$ Naveen Kalra $^{3}$ Shyamkumar N. Keshava ${ }^{1}$ \\ ${ }^{1}$ Department of Radiodiagnosis, Christian Medical College, Vellore, \\ Tamil Nadu, India \\ 2Department of Diagnostic and Interventional Radiology, All India \\ Institute of Medical Sciences, Jodhpur, Rajasthan, India \\ Address for correspondence Shyamkumar N. Keshava, DMRD, \\ DNB, FRCR, FRANZCR, Department of Interventional Radiology, \\ Christian Medical College, Vellore 632004, Tamil Nadu, India \\ (e-mail: shyamkumar.n.keshava@gmail.com).
}

${ }^{3}$ Department of Radiodiagnosis, Post Graduate Institute of Medical Education \& Research, Chandigarh, India

Ann Natl Acad Med Sci (India):2021;57:45-52

\begin{abstract}
Objective The aim of this study was to gather the opinion of medical practitioners in India regarding the modifications in the recently released $\mathrm{MCl}$ (Medical Council of India) circular for faculty promotion criteria across medical colleges in the country and their suggestions for further changes.

Materials and Methods An 11-set validated online questionnaire was circulated among medical practitioners across various medical colleges in the country, open for a period of 8 days between 5 to 12 June, 2020. The participants in this online survey were asked to rank the order of authors and types of manuscripts on a scale of 0 to 1 with increments of 0.1 and were also asked for an opinion regarding indexing, inclusion of impact factor of the journal, and citation indices.

Results There were 182 respondents included in the survey, belonging to 12 different states. Majority of the doctors participating in the survey were professors $(37.3 \%$, $68 / 182$ ). About $81.3 \%(148 / 182)$ doctors were aware of the latest $\mathrm{MCl}$ guidelines. Opinion for adding citations to the promotion criteria was expressed by $59.3 \%$

Keywords

- authorship

- medical faculty

- promotion

- publications

- research

- amendment (108/182). There was a general suggestion to include number of citations, and Google Scholar as citation service. A scoring table was proposed based on the responses, to rank various publications.

Conclusion As per the survey, more than $80 \%$ of the medical practitioners were aware of the recent update by $\mathrm{MCl}$ for faculty promotion. The participants expressed that the exiting guidelines may be further modified by the inclusion of all authors and all types of manuscripts into the criteria, based on a graded score system.
\end{abstract}

\section{Introduction}

The Medical Council of India (MCI) is the supreme authority for framing laws and regulations for the education system in medical colleges across the whole country. ${ }^{1}$ It has

published online February 1, 2021
DOI https://doi.org/

$10.1055 / \mathrm{s}-0040-1722382$ ISSN 0379-038X. recommended minimum qualifications mandatory for appointment and promotion of faculty in teaching positions. The two main criteria for promotion are the duration of service and the number of publications. The "Minimum Qualifications for Teachers in Medical Institutions

(C) 2021. National Academy of Medical Sciences (India).

This is an open access article published by Thieme under the terms of the Creative Commons Attribution-NonDerivative-NonCommercial-License, permitting copying and reproduction so long as the original work is given appropriate credit. Contents may not be used for commercial purposes, or adapted, remixed, transformed or built upon. (https://creativecommons.org/licenses/by-nc-nd/4.0/). Thieme Medical and Scientific Publishers Pvt. Ltd. A-12, 2nd Floor, Sector 2, Noida-201301 UP, India 
Regulations, 1998" came out with the criteria of publications for the first time in 2009. Since then, it has undergone amendments from time to time (-Table 1) intending to encourage clinical research and maintain uniform standards of medical faculty throughout the country. ${ }^{2-6}$ However, many medical professionals have voiced their opinions about the confusion surrounding the evolving guidelines. ${ }^{7-13}$ Concerns have been raised regarding credit given to only the first and corresponding author, the inclusion of only original research papers, exclusion of publications in "e-journals," lack of clarity in the list of indexing databases, and unnecessary categorization of journals as national or international.

The latest MCI amendment, through Gazette Notification No. MCI-12(2)/ 2019-Med.Misc./189334 on February 12, $2020,{ }^{2}$ has addressed some of the previously raised concerns, but certain manuscript types and author positions continue to be excluded from the promotion criteria. We conducted a short survey to gather the opinion of the doctors regarding the changes in the latest $\mathrm{MCI}$ amendment and offer a few suggestions to the existing faculty promotion criteria.

\section{Materials and Methods}

We created an 11-set online questionnaire ( $\mathbf{- T a b l e ~} \mathbf{2}$ ) based on the current publication criteria for medical staff promotion on Google forms. The questionnaire was internally validated by circulating among 20 medical practitioners belonging to different specialties and incorporating modifications based on their inputs, before the actual survey. A sample size of minimum 100 participants was calculated. The validated Google forms were then circulated to $\sim 1,000$ medical practitioners in the country for a period of 8 days (June 5 to June 12, 2020). There were some questions to determine the demographics of the participants, medial qualifications, specialty, and city of work. The target population included postgraduate trainees to professors in institutions belonging to all specialties to introduce heterogeneity in the participants. The survey was entirely electronic, anonymous, and participation was voluntary. Consent was obtained from each participant. The respondents were asked to rank author positions and manuscript types numerically, on a scale of 0 to 1 with increments of $0.1 ; 1$ being the score for best publication. They were also asked for an opinion regarding the inclusion of nonindexed journals, impact factor of the journal, number of citations, and Google Scholar as citation index service.

\section{Results}

There were 184 participants belonging to 12 different states, out of which 2 were excluded as their consent could not be obtained. Majority of the doctors participating in the survey were professors $(37.3 \%, 68 / 182)$, followed by assistant professors $(23.6 \%, 43)$, senior residents $(9.8 \%, 18)$, associate professors $(10.9 \%, 20)$, non-medical college doctors $(8.8 \%, 16)$, and

Table $1 \mathrm{MCl}$ amendments regarding faculty promotion over the years

\begin{tabular}{|c|c|c|c|c|c|}
\hline $\begin{array}{l}\text { Year of } \\
\text { amendment } \\
\text { notification }\end{array}$ & 2009 & 2010 & 2015 & 2017 & $\begin{array}{l}2019 \text { (circular dated } \\
\text { February 2020) }\end{array}$ \\
\hline Circular date & $\begin{array}{l}\text { No.MCl-12(2)/ } \\
2009 \\
\text {-Med. Misc. / } \\
56925\end{array}$ & $\begin{array}{l}\text { No.MCl- } \\
\text { 12(2)/2010-Med. } \\
\text { Misc. /33038 }\end{array}$ & $\begin{array}{l}\text { No.MCl-12(1)/2015- } \\
\text { TEQ/ } 131880\end{array}$ & $\begin{array}{l}\text { No.MCl- } \\
\text { 12(1)/2017-Med. } \\
\text { Misc./115698 }\end{array}$ & $\begin{array}{l}\text { No.MCl-12(2)/2019- } \\
\text { Med.Misc./189334 }\end{array}$ \\
\hline $\begin{array}{l}\text { Number of publica- } \\
\text { tions (assistant to } \\
\text { associate professor) }\end{array}$ & At least two & At least two & At least two & At least two & At least one \\
\hline Manuscript type & $\begin{array}{l}\text { Original research } \\
\text { paper }\end{array}$ & $\begin{array}{l}\text { Original research } \\
\text { paper }\end{array}$ & $\begin{array}{l}\text { Original research } \\
\text { articles } \\
\text { Original research } \\
\text { papers }\end{array}$ & $\begin{array}{l}\text { Original research } \\
\text { articles } \\
\text { Original research } \\
\text { papers }\end{array}$ & $\begin{array}{l}\text { Original articles } \\
\text { Systematic reviews } \\
\text { Meta-analysis } \\
\text { Case series }\end{array}$ \\
\hline Authorship & First author & $\begin{array}{l}\text { First author, second } \\
\text { author }\end{array}$ & $\begin{array}{l}\text { First author, second } \\
\text { author }\end{array}$ & $\begin{array}{l}\text { First author, } \\
\text { corresponding } \\
\text { author }\end{array}$ & $\begin{array}{l}\text { First three authors or the } \\
\text { corresponding author }\end{array}$ \\
\hline $\begin{array}{l}\text { Nationality of } \\
\text { journal }\end{array}$ & $\begin{array}{l}\text { Journals by } \\
\text { the National } \\
\text { Associations/ } \\
\text { Societies }\end{array}$ & $\begin{array}{l}\text { National journal } \\
\text { accepted/published }\end{array}$ & $\begin{array}{l}\text { National/international } \\
\text { journal }\end{array}$ & $\begin{array}{l}\text { National/interna- } \\
\text { tional journal }\end{array}$ & Removed both words \\
\hline Indexing agencies & $\begin{array}{l}\text { Choice of index- } \\
\text { ing services not } \\
\text { specified }\end{array}$ & $\begin{array}{l}\text { Choice of indexing } \\
\text { services not } \\
\text { specified }\end{array}$ & $\begin{array}{l}\text { Scopus } \\
\text { PubMed } \\
\text { Medline } \\
\text { Embase } \\
\text { Excerpta } \\
\text { Medica } \\
\text { Index medicus } \\
\text { Index Copernicus }\end{array}$ & $\begin{array}{l}\text { Scopus } \\
\text { PubMed } \\
\text { Medline } \\
\text { Embase } \\
\text { Excerpta } \\
\text { Medica } \\
\text { Index medicus } \\
\text { Index Copernicus }\end{array}$ & $\begin{array}{l}\text { Directory of Open access } \\
\text { journals (DoAJ) } \\
\text { PubMed Central } \\
\text { Citation index } \\
\text { Sciences citation index } \\
\text { Expanded Embase } \\
\text { Medline } \\
\text { Scopus }\end{array}$ \\
\hline E-journals & Not included & Excluded & Excluded & Excluded & DOAJ included \\
\hline
\end{tabular}


Table 2 Survey questionnaire

\begin{tabular}{|c|c|c|c|c|c|c|c|}
\hline \multirow{2}{*}{$\begin{array}{l}\text { No. } \\
1\end{array}$} & \multirow{2}{*}{$\begin{array}{l}\text { Survey questions } \\
\text { My academic position }\end{array}$} & \multicolumn{6}{|c|}{ Options } \\
\hline & & $\begin{array}{l}\text { Postgraduate } \\
\text { trainee }\end{array}$ & $\begin{array}{l}\text { Senior } \\
\text { resident }\end{array}$ & $\begin{array}{l}\text { Assistant } \\
\text { professor }\end{array}$ & $\begin{array}{l}\text { Associate } \\
\text { professor }\end{array}$ & Professor & $\begin{array}{l}\text { Doctor (not in a medical } \\
\text { college }\end{array}$ \\
\hline 2 & My specialty & & & & & & \\
\hline 3 & My city of work & & & & & & \\
\hline 4 & $\begin{array}{l}\text { I am aware of recent } \\
\text { update from } \mathrm{MCl} \text { (Feb } \\
2020 \text { ) regarding the } \\
\text { publication criteria for } \\
\text { faculty promotion }\end{array}$ & Yes/no & & & & & \\
\hline 5 & $\begin{array}{l}\text { I am in favor of inclu- } \\
\text { sion of scoring system } \\
\text { in promotion criteria }\end{array}$ & Yes/no & & & & & \\
\hline \multirow[t]{5}{*}{6} & \multirow{5}{*}{$\begin{array}{l}\text { My score for each } \\
\text { author position }\end{array}$} & \multicolumn{2}{|l|}{ First author } & \multirow{5}{*}{\multicolumn{4}{|c|}{0 (least) / $0.1 / 0.2 / 0.3 / 0.4 / 0.5 / 0.6 / 0.7 / 0.8 / 0.9 / 1.0$ (best) }} \\
\hline & & \multicolumn{2}{|l|}{ Second author } & & & & \\
\hline & & \multicolumn{2}{|l|}{ Third author } & & & & \\
\hline & & \multicolumn{2}{|c|}{ Corresponding author } & & & & \\
\hline & & \multicolumn{2}{|l|}{ Other authors } & & & & \\
\hline \multirow[t]{10}{*}{7} & \multirow{10}{*}{$\begin{array}{l}\text { My score for each } \\
\text { type of manuscript }\end{array}$} & \multicolumn{2}{|l|}{ Original article } & \multirow{10}{*}{\multicolumn{3}{|c|}{0 (least) / $0.1 / 0.2 / 0.3 / 0.4 / 0.5 / 0.6 / 0$}} & $0.8 / 0.9 / 1.0$ (best) \\
\hline & & \multicolumn{2}{|c|}{ Systematic review } & & & & \\
\hline & & \multicolumn{2}{|l|}{ Meta-analysis } & & & & \\
\hline & & \multicolumn{2}{|l|}{ Case series } & & & & \\
\hline & & \multicolumn{2}{|l|}{ Pictorial essay } & & & & \\
\hline & & \multicolumn{2}{|l|}{ Case report } & & & & \\
\hline & & \multicolumn{2}{|c|}{ Short communication } & & & & \\
\hline & & \multicolumn{2}{|l|}{ Letter to editor } & & & & \\
\hline & & \multicolumn{2}{|l|}{ Editorials } & & & & \\
\hline & & \multicolumn{2}{|l|}{ Book chapter } & & & & \\
\hline 8 & $\begin{array}{l}\text { If weightage for a } \\
\text { publication in MCl } \\
\text { indexed journal is } 1 \text {, } \\
\text { my score for publica- } \\
\text { tion in nonindexed } \\
\text { journals }\end{array}$ & \multicolumn{6}{|c|}{0 (least) / $0.1 / 0.2 / 0.3 / 0.4 / 0.5 / 0.6 / 0.7 / 0.8 / 0.9 / 1.0$ (best) } \\
\hline 9 & $\begin{array}{l}\text { Should number of } \\
\text { citations be included } \\
\text { in promotion criteria }\end{array}$ & \multicolumn{6}{|l|}{ Yes/no } \\
\hline 10 & $\begin{array}{l}\text { Should Google } \\
\text { Scholar be included as } \\
\text { citation index service }\end{array}$ & \multicolumn{6}{|l|}{ Yes/no } \\
\hline 11 & Comments & & & & & & \\
\hline
\end{tabular}

postgraduate trainees $(9.3 \%, 17)$. A small population of doctors (18.6\%, 34/182) admitted to not being aware of the latest MCI guidelines. The single largest group of respondents belonged to radiology $(25.8 \%, 47)$. Out of 182 doctors, 170 doctors were in favor of a scoring system for publications. Majority (59.3\%, 108) felt that the number of citations should be added to the promotion criteria and Google Scholar can be included as a citation index service. Majority $(93.9 \%, 171)$ was in favor of giving some weightage to nonindexed journals.

\section{Discussion}

The survey results reflect the current knowledge and suggestions for improvement. It is good to know that nearly $81 \%$ of the candidates were aware of the recent $\mathrm{MCI}$ amendment. The currently selected types of manuscripts like original articles are rated high by the participants, scores being closer to 1 . Majority of the participants $(93.4 \%, 170 / 182)$ expressed that all types of manuscripts should be recognized 
with appropriate weightage. A second striking observation was regarding the position of the authors. The participants wanted the best recognition for first and corresponding authors, with lesser weightage for authors in other positions. We reviewed the relevant literature under the following headings:

\section{Current Practice in Indian Medical Colleges}

All the $\mathrm{MCI}$ recognized medical colleges across the country mandatorily follow the minimum guidelines for faculty promotion laid down by the MCI. These guidelines are applicable for postgraduate teachers with qualifications including MD, MS, DNB, DM, and MCh. There may be internal variations in the practices in autonomous institutes such as the addition of average citation index and Journal Impact factor to the promotion criteria recommended by the Sneh Bhargava-Committee ${ }^{14}$ currently not a part of $\mathrm{MCI}$ guidelines, but the overall criteria cannot be lower than the minimum guidelines already set by the MCI.

\section{Modifications in $\mathrm{MCl}$ Amendment 2019}

\section{Number of publications}

The latest amendment has reduced the requirement of number of publications for the post of assistant to associate professor from two to a single research paper. Associate professors will require three (at least two as associate professor) instead of four publications for promotion to the post of professor.

\section{Indexing agencies}

For a publication to be counted toward promotion, $\mathrm{MCI}$ mandates that the article should be in indexed journals, but there was ambiguity in the list of recognized indexes in the previous amendments. For example, the first list of indexes in the 2015 issue omitted certain reputed indexes, duplicated the names of the same type of database (Medline and Index Medicus), and enlisted search engines like PubMed. ${ }^{7}$ In the latest (2019) amendment, the updated list of acceptable indexing agencies includes PubMed Central, Science Citation Index, Embase/Excerpta Medica, Scopus, and IndMED. ${ }^{2}$ This is a welcome move.

Clearly, the aim is to encourage publications in recognized databases that are reputed to have quality journals and limit predatory publishing. . $^{15,16}$

\section{Type of articles}

In the 2017 guidelines, original research papers were the only type of publication eligible for faculty promotion. Perhaps, the idea behind it is that "original research articles" are the best type of publication and an ideal parameter to judge the research output.

MCI has now included meta-analysis, systematic reviews, and case series in the list. However, we note that multiple other types of publications such as review articles, guidelines, pictorial essays, opinions, case reports, brief reports, and letters to the editor continue to be ignored and not included. Book chapters are also not considered. These types of publications are more in number, sometimes have a higher number of citations, are a valuable contributor to the knowledge pool, and serve as motivation for publications. ${ }^{17}$ Not giving importance to them discourages the aspiring authors to share their learning and experiences.

In the Indian scenario, due to the multiple challenges, it may not be possible for medical faculty in all specialties to generate multiple best quality or "ideal" publications such as original articles in indexed journals. One such challenge is where there are very few journals covering a specialty. Another is that each journal accepts a limited number of different categories of manuscripts. Case reports, pictorial essays, and brief reports may be the way for authors to share the knowledge from rare cases that may not be in a sufficient number to create an original article, especially in smaller or peripheral institutions or from a single institution. Letters to the editor constitute an extremely important segment for sharing of ideas and raising pertinent points to a recent manuscript and would be especially useful for authors from smaller setups to share their novel experiences about a standard approach/treatment regimen.

\section{Position in authorship sequence}

The 2017 amendment gives credit to only the first and corresponding author. The idea is perhaps to avoid gift authorships to the other authors because generally the majority of the work is done by the initial authors. ${ }^{18,19}$ This rule has been relaxed in the latest circular and the author must now be among the first three or should be the corresponding author.

We appreciate this step as it encourages contribution by multiple authors, promotes healthy interdisciplinary collaboration that should ultimately help bring out good quality work. However, the contributions of the rest of the authors lower down on the list continue to get neglected. Often, the senior teachers who mentor and supervise the work of junior doctors put themselves at the end of the list, so it is unfair to assume that the authors lower down the order did not contribute. In fact, the last author is increasingly being credited as being the guarantor of a study ${ }^{19,20}$

\section{Inclusion of electronic journals}

None of the previous guidelines considered the publications in e-journals for academic promotion. Unfortunately, this excluded many high-quality popular indexed journals with impact factor that are only available online. Some journals are purely in electronic format or have different content in the hard and electronic copy formats.,21

The publishing trend is switching from hard copy to the electronic format due to cost factor, space, and ease of access. Hard copies may not be always available for the readers in libraries in all institutions. A majority of learning now happens online on personal gadgets; visits to the library and borrowing journals are passé. Sometimes issues regarding the printing of hard copies may arise; for instance, the coronavirus disease scenario has put the publishing of print issues on hold and the new publications are increasingly being made available as soft copies. ${ }^{22}$ Most of the electronic journals have the option of displaying the manuscript online ahead of the 
issue with an assigned digital object identifier (DOI), which enables quick dissemination of knowledge. DOI even enables further citations even before publication date.

MCI has now included publications in the directory of open access journals (DOAJ) along with other databases. DOAJ is a freely available, digital online directory that indexes and provides access to high quality, open access, peer-reviewed journals. ${ }^{23}$ This allows a much wider range of journals for the faculty to choose from, for publishing their work.

\section{Removal of "specialty," "national," and "international" journals}

The 2017 amendment included "national" or "international" journals in the eligibility criteria. Several articles pointed out that since indexing had already been included as a criterion, separate mention of these terms did not have any added value. ${ }^{6}$ The 2019 guidelines have made note of this and have only given importance to indexed journals regardless of nationality. The criteria for "specialty" journals have also been removed, which will encourage multidisciplinary and multicenter collaboration for research.

7. Noninclusion of other pillars of education: service and teaching

$\mathrm{MCl}$ amendments give importance to publications (number and type) for assessing medical faculty for promotion. However, it discounts achievements and prowess in clinical or laboratory/ imaging services and teaching, which are the core responsibilities of medical faculty. The pressure to give disproportionate importance to research output for assessment and not giving due consideration to other aspects of their duty negatively affects the purpose of teaching and service. It results in a desperate need for publications for promotions, leading to poor quality publications in "predatory journals." It also creates stress and leads to below standard research. A good teacher could potentially be considered "inferior" to a colleague with a higher number of publications and thus promoted to a higher designation.

\section{Two years' transitory period}

The time interval between amendment notification and the faculty appointment or promotion of two years is appreciable, as it allows the new guidelines prospectively applicable to the new promotions and there is no threat to the positions of the teachers, whose promotions were as per the old guidelines. The already existing publications or those accepted for publication before the notification will also not be affected.

\section{Our Suggestions}

\section{Scope for a scoring system (-Table 3)}

The criteria for promotions should include the quality of publications and not just their quantity. The DCI (Dental Council of India), a parallel medical education system, already has a point system in place regarding the types of publications for academic promotions. ${ }^{24}$ Why not take a cue from it and adopt a similar system as an objective method to quantify research productivity?
Table 3 Suggestions for publication criteria for medical promotions

\begin{tabular}{|c|c|c|}
\hline \multicolumn{3}{|l|}{ Proposed modifications } \\
\hline \multirow{6}{*}{$\begin{array}{l}\text { 1. Objective criteria: Inclusion } \\
\text { of scoring system }\end{array}$} & \multicolumn{2}{|c|}{ Appropriate weightage to: } \\
\hline & & All types manuscripts \\
\hline & & All authors \\
\hline & & $\begin{array}{l}\text { Indexed as well as } \\
\text { non-indexed journals }\end{array}$ \\
\hline & & $\begin{array}{l}\text { Impact factor of the } \\
\text { journal }\end{array}$ \\
\hline & V. & Specialty journals \\
\hline
\end{tabular}

2. Weightage to total number of citations for each author and each paper: Inclusion of citation indices and Indexing service such as Google Scholar

3. Introduction of minimum publication guidelines with international equivalence

4. Common minimum publication guidelines for faculty promotion in university accepted fellowship programs

5. Inclusion of criteria to assess the quality of a medical teacher with regard to service and teaching

We propose a scoring template to rank the quality of publications based on both participants' scores and input from the authors (-Table 4). For example, although the survey results suggest an average score of 0.5 to case reports making two case reports cumulatively equivalent to an original article, the authors suggest a lower score of 0.2 per case report. We also propose that in the place of currently accepted "one publication," "one score" can be used as criteria for promotion. The ideal scoring should be inclusive, reasonably simple, support the career growth of the faculty, and encourage publications.

Any publication in a recognized index has value and should be acknowledged, as having some publication is better than none. A maximum score of 1 can be given to original research, meta-analysis, and systematic reviews in indexed journals as these are the ideal publications one should aim for. A minimum score of 0.1 would represent a publication of low academic value, with no additional information, perhaps in a nonindexed journal. Textbook chapters should also be given some weightage, as medical students often rely upon textbooks more than research articles as their preferred reading source for basic and comprehensive learning of the subject. Multiple publications of a lesser score in different formats can then be given a cumulative score together, to make them equivalent to one "ideal" publication. This will reflect the efforts of the author and also show the continuous academic activity of the author in terms of publications.

Similarly, all authorship should be acknowledged and points can be given based on the contribution and serial order in author sequence. A maximum score can be awarded to the first and corresponding authors and lesser scores to the remaining authors. This can address the uncertainty in the authorship criteria persisting over the years, prevent the 
Table 4 The proposed weightage-based scoring system (1 = best score)

\begin{tabular}{|c|c|c|c|c|c|}
\hline Type of manuscript & Author position & Specialty & Index & $\begin{array}{l}\text { Journal impact } \\
\text { factor }\end{array}$ & Recommended score \\
\hline $\begin{array}{l}\text { a. Original articles } \\
\text { b. Systematic reviews } \\
\text { c. Meta-analysis } \\
\text { d. Case series }\end{array}$ & First/corresponding & Same & $\begin{array}{l}\mathrm{MCl} \text { recognized } \\
\text { index }\end{array}$ & More than one & 1 \\
\hline $\begin{array}{l}\text { a. Original articles } \\
\text { b. Systematic reviews } \\
\text { c. Meta-analysis } \\
\text { d. Case series } \\
\text { e. Book chapters }\end{array}$ & $\begin{array}{l}\text { Second or third } \\
\text { author }\end{array}$ & Same & $\begin{array}{l}\mathrm{MCl} \text { recognized } \\
\text { index }\end{array}$ & More than one & 0.8 \\
\hline $\begin{array}{l}\text { a. Pictorial essays } \\
\text { b. Case reports } \\
\text { c. Technical reports } \\
\text { d. Book chapters }\end{array}$ & First/corresponding & Same & $\begin{array}{l}\mathrm{MCl} \text { recognized } \\
\text { index }\end{array}$ & Less than one & 0.5 \\
\hline $\begin{array}{l}\text { a. Case report } \\
\text { b. Letter to the Editor } \\
\text { c. Short communication }\end{array}$ & First/corresponding & $\begin{array}{l}\text { Other } \\
\text { specialty }\end{array}$ & $\begin{array}{l}\mathrm{MCl} \text { recognized } \\
\text { index }\end{array}$ & Less than one & 0.3 \\
\hline $\begin{array}{l}\text { a. Original articles } \\
\text { b. Systematic reviews } \\
\text { c. Meta-analysis } \\
\text { d. Case series } \\
\text { e. Case report } \\
\text { f. Letter to the Editor } \\
\text { g. Short communication }\end{array}$ & $\begin{array}{l}\text { Rest of the authors } \\
\text { (other than first or } \\
\text { corresponding) }\end{array}$ & $\begin{array}{l}\text { Other } \\
\text { specialty }\end{array}$ & $\begin{array}{l}\mathrm{MCl} \text { recognized } \\
\text { index }\end{array}$ & Any & 0.2 \\
\hline Any & Any author & Any & Nonindexed & Any & 0.1 \\
\hline
\end{tabular}

Abbreviation: $\mathrm{MCl}$, Medical Council of India.

pressure of gift authorship, and encourage multidisciplinary and multi-institutional research.

Some journals allow dual or joint first authorship. ${ }^{25}$ There is no mention in the existing $\mathrm{MCl}$ guidelines regarding recognition or weightage for joint first co-authors. We feel that an equal weightage can be given to joint first authors, preferably for original articles of multidisciplinary nature. We assume that an equal contribution by authors would have been justified and subsequently approved by the editorial committee. Hopefully, this should not be considered as an opportunity to achieve a higher number of authors than what $\mathrm{MCI}$ is currently accepting for promotion.

Nonindexed journals, journals with low impact factor (of less than one), and non-specialty journals though of lesser quality, can be incorporated into the scoring system and given a minimum score.

It is interesting to note that $12 / 182(6.5 \%)$ of participants have suggested a zero score (nil weightage) for publications. One cannot be sure of their reasoning, but these teachers are likely of the opinion that there is currently undue importance given to publications for promotions.

\section{Journal impact factor score}

Impact factor does not feature in any of the $\mathrm{MCI}$ amendments, though it is recognized worldwide as an objective criterion to assess the quality of different journals based on citation data. A value of more than one is considered as an internationally competent and influential journal, irrespective of the country or index of publication. ${ }^{26-28}$ We suggest that this can also be incorporated into the scoring system and publications be given appropriate points based on the numerical value of impact factor of a journal.

3. Inclusion of citation indices and Google Scholar as a Citation Indexing Service

Impact factor measures the overall quality of a journal, but not the scientific impact of an individual article or author. These can be assessed by the total number of citations (from all published material) and citation indices such as h-factor and i10 index..$^{29}$ Google Scholar is a freely-accessible online indexing service that includes scientific journals as well as nonjournal sources such as books, dissertations, and conference papers in its database. It can determine the total number of citations 
and rank them for each author (quantity) and each paper (quality). ${ }^{30}$ The number of times a publication or an author has been cited per year using Google Scholar can be taken into consideration for the assessment of faculty promotion.

\section{Criteria for further grading within a category of faculty}

The present guidelines address the publication criteria only at two senior levels: associate professor and professor. In some institutions, the associate professor is promoted to an intermediate position of "additional professor" before becoming a professor based on the years of experience. ${ }^{31}$ We feel that certain publication criteria can be introduced at this level as well.

\section{International and universal}

There is a wide diversity in the guidelines for faculty promotion in foreign universities, based on the information available on some of their web sites. Many institutes give due consideration to research activities, teaching as well as clinical skills and not just the number of publications. Some give equal weightage to all authors irrespective of their sequence in peer-reviewed papers, case reports, letters to the editor, syllabus materials, commentaries, review articles, book chapters, videos, and letters to the editor. ${ }^{32,33,34}$ In some institutes, faculty is appointed separately in either research or teaching and there is no requirement for formal teaching or clinical care in the research line.

It may not be possible for us to have universally applicable guidelines, but at least it would be great if "common minimum" guidelines be achieved, so that the qualifications of our teachers in terms of research can be aligned with the accepted standards for the similar job positions overseas.

\section{Assessment criteria for service and teaching}

We believe that the other important facets of a physicianteacher-service, teaching, and mentoring, which have not been taken into consideration for promotion (along with years of experience), should definitely be seriously considered. These may include teaching skills, examination duties, fellowships, service record, and other academic achievements such as awards, patents, collaborations with projects, grants brought to the institution, orations, guest lectures, organizing conferences, the performance of students, and their feedback. Mentoring postgraduate students for dissertations, reviewing manuscripts, and working as an editor should also be considered as a part of research activities. We can adopt criteria similar to the already existing academic performance indicators scores devised by the UGC for other fraternities. ${ }^{35}$

7. Common minimum guidelines for faculty in other streams of higher medical education

The new MCI guidelines apply to teachers in institutes with DNB and DM/M.Ch. super specialty courses as well. We need clarity regarding how exactly to translate academic positions between these two streams. Apart from them, there are institutes with only university accepted fellowship programs, without undergraduate or postgraduate courses. The faculty of such institutes also contributes to the pool of medical teachers and should have a defined publication criterion.

\section{Limitations}

The study was conducted online through closed social media groups. The participants had self-declared to be medical college faculty. The scoring system we have proposed may appear elaborate and perhaps add to the complexity of the promotion criteria. Selection bias may have been introduced in the study as a small number of medical professionals have responded. Majority of the participants were radiologists as the investigators are from the same specialty. A small percentage of the participants were not aware of the recent $\mathrm{MCI}$ guidelines and hence it is possible that their inputs would have been different if they knew the guidelines.

\section{Conclusion}

Publications reflect the efforts of the authors and having some publication is better than none. The survey results supported that the publication criteria should not be "all or none" and need to be modified at regular intervals to facilitate appropriate weightage for the types of manuscript and author positions.

While appreciating the relaxations introduced in the latest amendment, we hope that our proposition of a scoring system to give due credit to all types of manuscripts and all authors will be given a thought. These steps will further motivate our teachers to participate in quality research and share their learning experience and creativity, without the desperate need of indulging in unethical research practices for the sake of promotion.

\section{Key Message}

Publications should be judged based on their quality not quantity. A scoring system can be followed to give appropriate weightage to different types of manuscript and author positions for faculty promotion in our medical institutes.

\section{Conflict of Interest}

None declared.

\section{References}

1 MCI India [cited 2020 Jun 6]. Available at: https://www.mciindia.org/CMS/. Accessed December 5, 2020

2 Medical Council of India. No. MCI-12(2)/2019-Med. Misc./189334. Available at: https://www.mciindia.org/ ActivitiWebClient/open/getDocument?path=/Documents/ Public/Portal/Gazette/TEQ-17.02.2019.pdf. Accessed December 5, 2020

3 Medical Council of India. No. MCI-12(2)/2009-MED-22654. Available at: https://old.mciindia.org/Rules-andRegulation/Gazette\%20Notifications\%20-\%20Amendments/ teq-21.07.2009.pdf. Accessed December 5, 2020 
4 Medical Council of India. No. MCI-12(2)/2010-Med.Misc./33038. Available at: https://old.mciindia.org/Rules-andRegulation/Gazette\%20Notifications\%20-\%20Amendments/ TEQ-03.11.2010.pdf. Accessed December 5, 2020

5 Medical Council of India. Clarification with regard to research publications in the matter of promotion for Teaching faculty in a medical college/Institutions. Available at: https://www. mciindia.org/documents/TEQ/Circular-03.09.2015-TEQPromotion-Publication.pdf. Accessed December 5, 2020

6 Medical Council of India. Minimum Qualifications for Teachers in Medical Institutions Regulations, 1998 (Amended upto 8th June, 2017). Available at: http://www.mciindia.org/ Rules-and-Regulation/Teachers-Eligibility-QualificationsRgulations-1998.pdf. Accessed December 5, 2020

7 Aggarwal R, Gogtay N, Kumar R, Sahni P. The revised guidelines of the Medical Council of India for academic promotions: need for a rethink. Natl Med J India 2016;29(1):1-5

8 Bandewar SV, Aggarwal A, Kumar R, Aggarwal R, Sahni P, Pai SA. Medical Council of India's amended qualifications for Indian Medical Teachers: well intended, yet half-hearted. Natl Med J India 2018;31(1):1-4

9 Bandewar SVS, Pai SA. Regressive trend: MCl's approach to assessment of medical teachers' performance. Indian J Med Ethics 2015;12(4):192-195

10 Dhulkhed VK, Kurdi MS, Dhulkhed PV, Ramaswamy AH. Faculty promotions in medical institutions in India: can we improve the criteria? Indian J Anaesth 2016;60(11):796-800

11 Kumar A. Judging credential of medical teachers through publication: How far it is fruitful? Asian J Med Sci 2018;9:52-54

12 Doshi SM. "Teaching experience and research publications" quantity matters and quality suffers, a medical teacher perspective. Indian J Pharmacol 2018;50(3):144-146

13 Jain MK, Thawani V, Totade S. MCI challenges to manuscript writing and publishing. J Rational Pharmacother Res An Official Publication of ISRPT 2018;4:6-8

14 Sneh Barghava Committee Report.pdf. Available at: https:// www.aiims.edu/aiims/committee/Sneh\%20Barghava\%20 Commitee\%20\%20Report.PDF. Accessed December 5, 2020

15 Berger M. Everything you ever wanted to know about predatory publishing but were afraid to ask. ACRL 2017;206-207

16 Das AK. Publish and flourish: take the road less travelled! Med J Armed Forces India 2017;73(2):178-180

17 Bavdekar SB, Save S. Writing case reports: contributing to practice and research. J Assoc Physicians India 2015;63(4):44-48

18 Zaki SA. Gift authorship - a cause for concern. Lung India 2011;28(3):232-233

19 Zbar A, Frank E. Significance of authorship position: an open-ended international assessment. Am J Med Sci 2011;341(2):106-109

20 Bhattacharya S. Authorship issue explained. Indian J Plast Surg 2010;43(2):233-234

21 Bavdekar SB, Tullu MS. Research publications for academic career advancement: an idea whose time has come. But is this the right way? J Postgrad Med 2016;62(1):1-3
22 Covid-19 hits print media hard - ads and circulation dip editions see major digital push [Internet]. [cited 2020 Jul 7]. Available from: https://theprint.in/india/covid-19-hits-printmedia-hard-ads-and-circulation-dip-editions-see-major-digital-push/388514/. Accessed December 5, 2020

23 Directory of Open Access Journals [Internet]. [cited 2020 Jun 6]. Available at: https://doaj.org/. Accessed December 5, 2020

24 24. Welcome To Dental Council of India. Available at: http://dciindia.gov.in/Rule_Regulation/MDS_Course_Regulations_2017. pdf. Accessed December 5, 2020

25 Lapidow A, Scudder P. Shared first authorship. J Med Libr Assoc 2019;107(4):618-620

26 The PLoS Medicine Editors. The impact factor game. It is time to find a better way to assess the scientific literature. PLoS Med 2006;3(6):e291

27 Azer SA, Holen A, Wilson I, Skokauskas N. Impact factor of medical education journals and recently developed indices: can any of them support academic promotion criteria? J Postgrad Med 2016;62(1):32-39

28 Nagoba B, Selkar S, Mumbre S, Davane M, Suryawanshi N. Where to publish? Choosing the right journal for research work. J Krishna Inst Med Sci Univ 2016;5:6

29 Azer SA, Holen A, Wilson I, Skokauskas N; SA. Impact factor of medical education journals and recently developed indices: can any of them support academic promotion criteria? J Postgrad Med 2016;62(1):32-39

30 Kulkarni AV, Aziz B, Shams I, Busse JW. Comparisons of citations in Web of Science, Scopus, and Google Scholar for articles published in general medical journals. JAMA 2009;302(10):1092-1096

31 Medical Professor careers [Internet]. [cited 2020 Jul 7]. Available at: https://www.indiaeducation.net/medical/medical-topic/medical-path/medical-professor-careers.html. Accessed December 5, 2020

32 Jackson JB, Professor B. Promotion at the Johns Hopkins School of Medicine. Available at: https://www.hopkinsmedicine.org/ women_science_medicine/_pdfs/promotion\%20overview\%20 brooks\%20jackson.pdf. Accessed December 5, 2020

33 School of Medicine Faculty Handbook. Stanford University. Available at: https://www.med.stanford.edu/academicaffairs/ administrators/handbook.html. Accessed December 5, 2020

34 Senior Academic Promotions Procedure and Guidance. 2015. University of Cambridge; 2015. Available at: http://www. admin.cam.ac.uk/offices/hr/promotion/. Accessed December 5, 2020

35 Proposed Scores for Academic Performance Indicators (APIs) in Recruitments and Career Advancement Scheme (CAS). Promotions of University/College Teachers. The Gazette of India: Extra Ordinary Part 3- Sec. 11. University Grants Commission Notification. New Delhi; 13 June, 2013. p. 17-30. Available at: http://www.bhu.ac.in/racbhu/regulation/8377302_English.pdf. Accessed December 5, 2020 